\title{
Undetectable plasma viral load predicts normal survival in HIV-2-infected people in a West African village
}

Maarten F Schim van der Loeff ${ }^{+1}$, Natasha Larke+2, Steve Kaye1, Neil Berry³, Koya Ariyoshi4, Abraham Alabi1, Carla van Tienen1', Aleksandra Leligdowicz', Ramu Sarge-Njie1, Zacharias da Silva5, Assan Jaye1, Dominique Ricard1, Tim Vincent ${ }^{5}$, Sarah Rowland Jones' ${ }^{1}$, Peter Aaby5, Shabbar Jaffar² and Hilton Whittle*1

\begin{abstract}
Background: There have been no previous studies of the long-term survival and temporal changes in plasma viral load among HIV-2 infected subjects.

Methods: 133 HIV-2 infected and 158 HIV-uninfected subjects from a rural area in North-west Guinea-Bissau, West Africa were enrolled into a prospective cohort study in 1991 and followed-up to mid-2009. Data were collected on four occasions during that period on HIV antibodies, CD4\% and HIV-2 plasma viral load.

Results: Median age (interquartile range [IQR]) of HIV-2 infected subjects at time of enrollment was $47(36,60)$ years, similar to that of HIV-uninfected control subjects, $49(38,62)(p=0.4)$. Median (IQR) plasma viral load and CD4 percentage were $347(50,4,300)$ copies/ml and $29(22,35)$ respectively.

Overall loss to follow-up to assess vital status was small, at $6.7 \%$ and $6.3 \%$ for HIV-2 infected and uninfected subjects respectively. An additional 17 (12.8\%) and 16 (10.1\%) of HIV-2 infected and uninfected subjects respectively were censored during follow-up due to infection with HIV-1. The mortality rate per 100 person-years (95\% CI) was 4.5 (3.6, 5.8) among HIV-2 infected subjects compared to $2.1(1.6,2.9)$ among HIV-uninfected (age-sex adjusted rate ratio 1.9 $(1.3,2.8, p<0.001)$ representing a 2 -fold excess mortality rate associated with HIV-2 infection.

Viral load measurements were available for $98 \%, 78 \%, 77 \%$ and $61 \%$ HIV-2 infected subjects who were alive and had not become super-infected with HIV-1, in 1991, 1996, 2003 and 2006 respectively. Median plasma viral load (RNA copies per $\mathrm{ml}$ (IQR) did not change significantly over time, being $150(50,1,554 ; n=77)$ in 1996, $203(50,2,837 ; n=47)$ in 2003 and $171(50,497 ; n=31)$ in 2006. Thirty seven percent of HIV-2 subjects had undetectable viraemia $(<100$ copies $/ \mathrm{ml}$ ) at baseline: strikingly, mortality in this group was similar to that of the general population.

Conclusions: A substantial proportion of HIV-2 infected subjects in this cohort have stable plasma viral load, and those with an undetectable viral load (37\%) at study entry had a normal survival rate. However, the sequential laboratory findings need to be interpreted with caution given the number of individuals who could not be re-examined.
\end{abstract}

\section{Background}

The sooty mangabey simian immunodeficiency virus (SIV), the ancestor of HIV-2, is estimated to have crossed from monkey to man around 1940, resulting in an outbreak of HIV-2 subtype A in West Africa [1]. HIV-2 has

\footnotetext{
* Correspondence: hwhittle@mrc.gm

1 MRC Laboratories Fajara, P.O. Box 273, Banjul, The Gambia + Contributed equally

Full list of author information is available at the end of the article
}

remained endemic in West Africa, and now in this region both HIV-2 and HIV-1 infections are prevalent, providing an opportunity to draw comparisons between the natural history and immunopathogenesis of the two viruses [2].

A prevalence of HIV-2 of $8-10 \%$ has been recorded in some settings [3], but is now thought to be stable or falling across West Africa [4]. Median survival of HIV-1 infected subjects in sub-Saharan Africa in the absence of antiretroviral therapy is about 10 years $[5,6]$, similar to 
that in developed countries, and plasma viral load and CD4 count have been identified as strong markers of prognosis $[7,8]$. Because of the paucity of communitybased HIV-2 cohorts, median survival with HIV-2 has not been widely documented, but survival with HIV-2 was longer than that with HIV-1 in a hospital-based study in Gambia, especially at higher CD4 count $[9,10]$. Similarly, in an urban community-based study among individuals more than 35 years old [11], 9-year HIV-2-associated mortality was only twice that of HIV-uninfected subjects [12]. The long-term survival of HIV-2 infected subjects is not known.

A number of studies have shown that HIV-2 infections are associated with lower plasma viral load [13], slower CD4 decline [14,15] and a lower incidence of AIDS [16] than HIV-1 in the same study populations. Also, CD4 count and plasma viral load in HIV-2 are predictors of mortality [17-20]. However, some of this evidence is from hospital-based studies which contained subjects with more advanced disease with a relatively short follow-up period. Whether these markers predict survival over the long-term in the community or the clinic is not known.

We have conducted a community-based cohort study of HIV-2 infected people in rural West Africa followed from 1991 through to 2009. Here we report changes in plasma viral load and survival over this 18-year followup, which is the longest on record and one of the few with laboratory variables.

\section{Methods}

\section{Study area and population}

The study was conducted in Caió, a village in north-western Guinea-Bissau, West Africa. The study comprised a population of about 10,000 individuals, mostly subsistence farmers. The sex ratio is unbalanced because many men migrate for work. Women may also leave in search for work in the region's urban centres.

A serological survey conducted in the community between 1989-1991 showed HIV-2 prevalence among adults aged $\geq 15$ years to be $8 \%$ ( 240 subjects), peaking at $19 \%$ in men aged $45-54$ years, and $17 \%$ in women aged 35-44 years [21]. HIV-2 infected subjects and an equal number of HIV-seronegative controls, broadly matched for age and sex, were visited at home by field staff. Those who were present at home and gave informed consent were invited to participate in the study [22]. Field staff were unaware of the HIV status of the study subjects.

Subjects were followed-up annually to record vital status (data collected up until mid-2009). They were also invited for a clinical examination and asked for a blood sample in 1991, 1996, 2003 and 2006. Blood samples were tested for HIV status, and those HIV-infected were tested for $\mathrm{CD} 4 \%$ and plasma viral load.
All subjects received pre-test counselling before HIV testing during each of the four study rounds. Post-test counselling and HIV test results were available for those who wanted to know their results. Subjects had access to a physician-led clinic and were offered free medical treatment, including that for anaemia, malaria, and syphilis, according to national guidelines. Prophylaxis against opportunistic infections with co-trimoxazole was offered from 1999 onwards to HIV infected subjects who were aware of their diagnosis and who were either symptomatic or had a $\mathrm{CD} 4 \%<28 \%$. Antiretroviral treatment was not available in Guinea-Bissau at the time of the field study, but is now in place.

\section{Laboratory methods}

The laboratory methods of the 1991 and 1996 study rounds are described by Wilkins et al. [21], Ricard et al. [22] and Berry et al. [20]; methods for 2003 and 2006 are described in Leligdowicz et al. [23]. In brief, for measuring HIV-2 plasma viral loads in 2003 and 2006, RNA was extracted from $200 \mu \mathrm{l}$ plasma using a silica gel purification method, and an aliquot of the extract equivalent to $40 \mu \mathrm{l}$ of the original sample was amplified in a single-tube reverse transcribed-PCR (Qiagen "One-Step", Hilden, Germany). A standard curve was generated using RNA extracted from cell culture supernatants of HIV-2 (strain CBL-23). Each reaction was spiked with approximately 100 copies of an internal control. This control was a $1 \mathrm{~kb}$ RNA molecular construct spanning the PCR primer binding sites and replacing the probe binding site with a 25 base randomised sequence. The control was extracted and co-amplified with the test sample and probed separately. Results were calculated as signal ratios of test sample to internal control and copy numbers determined by comparison with the standard curve. A positive control was included in every assay run to control for inter-assay variation. The assay had a dynamic range of 100 to $1,000,000$ RNA copies/ml of plasma. Samples with undetectable virus were assigned a value half that of the detection threshold of the test, for the purposes of analysis.

Twenty-nine samples of HIV-2 infected subjects taken in 1996 were re-assayed with the current method. The mean virus loads were $3.81 \log _{10}$ and $3.96 \log _{10}$ copies $/ \mathrm{ml}$ by old and current method respectively. Fifteen (52\%) were less than $0.5 \log _{10}$ different, and 25 (86\%) were within $1 \log _{10}$ difference; the agreement was acceptable [beta $=0.75$ (95\%CI 0.48, 1.02); $\mathrm{r}^{2}=0.55$ ].

We chose to analyse the $\mathrm{CD} 4$ data by percentage rather than by absolute count. In the early years of the epidemic, due to the lack of automated counting machines, we were obliged to estimate lymphocyte counts by manual methods which introduced considerable observer variation and error. Moreover a batch of slides from Caio destined 
for lymphocyte counting was damaged during transit on bad roads. Thus in addition to providing a more robust measurement, the use of CD4 percentage obtained by FACS analysis allowed us to use the full data set at baseline.

\section{Ethics}

This study was approved by the MRC Laboratories/Gambia Government Joint Ethics Committee, the London School of Hygiene \& Tropical Medicine Ethics Committee, and the Research Committee of the Ministry of Health of Guinea-Bissau.

\section{Statistical methods}

Continuous data were presented as medians and interquartile ranges (IQR), since these data were non-normally distributed. Continuous data were compared between groups using the Wilcoxon rank sum or KruskalWallis test. Categorical data were compared using the chi-squared test. Correlation was assessed using Spearman's correlation coefficient. Mortality rates were calculated using Poisson regression with time calculated from enrolment in 1991 to either the date of death or the end of the study in mid-2009 or the last date seen alive for those lost-to-follow-up (i.e. permanently moved away from the village or were not re-identified). HIV-2 infected subjects who also seroconverted to HIV-1 in a subsequent survey were censored from the date on which they were known to be infected with HIV-1. Controls who seroconverted to either HIV-1 or HIV-2 were censored likewise. Analyses were conducted using Stata 10 (Stata Corp, College Station, TX, USA).

\section{Results}

\section{Baseline characteristics}

In 1991, $133 \mathrm{HIV}-2$ infected and $158 \mathrm{HIV}$-uninfected subjects were enrolled. Almost all were from the Manjago ethnic group (Table 1). Median age (Interquartile range [IQR]) of HIV-2 infected subjects was $47(36,60)$ compared with $49(38,62)$ of HIV-uninfected subjects ( $\mathrm{p}=$ $0.4)$. The male: female ratio was similar among HIV-2 infected and HIV-uninfected subjects $(\mathrm{p}=0.4)$. Among HIV-2 infected subjects median (IQR) plasma viral load and CD4 percentage were $347(50,4,300)$ copies per $\mathrm{ml}$ and $29(22,35)$. Forty eight of the 130 subjects $(37 \%)$ who were tested had an undetectable level of virus $(<100$ copies/ml), whereas only 22 (17\%) had levels above 10,000 copies $/ \mathrm{ml}$. The median viral load was lower among women $(137$, IQR $50,127,000)$ compared to men $(755$, IQR 125, 286,000). Plasma viral load was associated inversely with CD4 percentage $(\mathrm{r}=-0.30, \mathrm{p}<0.001)$ but not with age $(r=0.07, \mathrm{p}=0.4)$.

\section{Follow-up and survival of HIV-2 and HIV-uninfected subjects}

Subjects were followed-up annually through to mid-2009, with blood samples collected in 1991, 1996, 2003 and 2006 (Figure 1). Loss to follow-up with regard to vital status was small, being $6.7 \%$ and $6.3 \%$ respectively for the infected and uninfected subjects respectively. In addition a further 17 (12.8\%) HIV-2 infected and 16 (10.1\%) uninfected subjects became infected with HIV-1 during follow-up. The proportion of HIV-2 infected and HIVuninfected subjects known to be alive in 1996, 2003, 2006 and 2008/9 and who did not seroconvert to HIV-1 were $74 \%$ and $83 \%, 46 \%$ and $66 \%, 38 \%$ and $60 \%$, and $31 \%$ and $53 \%$ respectively. The median (IQR) follow-up time was $11.8(5.3,17.3)$ years among HIV-2 infected subjects and 17.7 (9.5, 18.6) among HIV-uninfected subjects ( $\mathrm{p}<$ 0.001).

Baseline characteristics of those followed-up successfully through to $2008 / 09$, those who died and those lost to follow-up or censored are shown in Table 2. The distribution of age, sex, percentage CD4 and plasma viral load of those alive were similar to those lost to follow-up or censored, but differed substantially from those who died. The overall mortality rate per 100 person-years (95\% CI) was $4.5(3.6,5.8)$ among HIV-2 infected subjects compared to $2.1(1.6,2.9)$ among the HIV-uninfected population. Figure 2 shows the Kaplan-Meier survival of HIV-2 and HIV-uninfected subjects. Mortality increased with age and was higher among men than women, but this was true for both HIV-infected and HIV-uninfected subjects (Table 3). Thus the relative difference or rate ratio decreased with age. Among subjects 60 years or older in 1991, there was no significant difference in survival between HIV-2 and HIV-uninfected. Overall, the mortality rate ratio $(95 \% \mathrm{CI})$ adjusted for age category and sex was $1.9(1.3,2.8, \mathrm{p}<0.001)$. Mortality rates for both groups were marginally higher during 1999 to 2009 compared to the earlier time period (Table 3). The mortality of women compared with men was 0.42 (95\% CI 0.24 , 0.74) among HIV-uninfected subjects after adjusting for age category and 0.51 (95\% CI 0.31, 84) among HIV-2infected.

\section{Association between baseline CD4 percentage, plasma viral load and the mortality of HIV-2 infected subjects}

In the univariable analysis both plasma viral load and CD4 percentage were associated independently with mortality (Table 4). The association with plasma viral load was very strong (Figure 2). Mortality in those with undetectable viral load was similar to that of the uninfected subjects, whereas those with a viral load of 10,000 copies/ml or greater had a rate of 10.4 per 100 years, which is similar to that for HIV-1 in the region [11]. 
Table 1: Baseline characteristics in 1991.

\begin{tabular}{ccc}
\hline & $\begin{array}{c}\text { HIV-2 infected } \\
\mathbf{( N = 1 3 3 )}\end{array}$ & $\begin{array}{c}\text { Uninfected } \\
\mathbf{( N = 1 5 8 )}\end{array}$ \\
\hline $\begin{array}{c}\text { Age in years } \boldsymbol{~} \\
<30\end{array}$ & $13(10 \%)$ & $29(18 \%)$ \\
$30-39$ & $24(18 \%)$ & $27(17 \%)$ \\
$40-49$ & $39(30 \%)$ & $31(20 \%)$ \\
$50-59$ & $20(15 \%)$ & $32(20 \%)$ \\
$60-69$ & $28(21 \%)$ & $20(13 \%)$ \\
$\geq 70$ & $8(6 \%)$ & $19(12 \%)$ \\
Sex & & $43(27 \%)$ \\
Males & $42(32 \%)$ & $152(96 \%)$ \\
Ethnicity & & $6(4 \%)$ \\
\hline
\end{tabular}

a Data missing for one HIV-2 infected subject

${ }^{b}$ Data missing for one HIV-2 infected subject

In a multivariable analysis with age category, sex, plasma viral load category and CD4 percentage category, the association between mortality and plasma viral load became stronger. The adjusted rate ratio for the medium viral load category $(101-10,000$ copies $/ \mathrm{ml})$ was 2.0 $(95 \% \mathrm{CI} 1.0,4.2)$ and $5.6(95 \% \mathrm{CI} 2.5,12.5)$ for the high viral load category ( $>10,000$ copies $/ \mathrm{ml}$ ). When plasma viral load was analysed on a continuum, the adjusted mortality ratio was $1.8(95 \% \mathrm{CI} 1.4,2.3 ; \mathrm{p}<0.0001)$ for every $\log _{10}$ increase in viral load.

In the multivariable analysis, there was no evidence of an association between CD4 percentage and mortality. The adjusted rate ratio for those with a CD4 percentage $<28 \%$ compared with $\geq 28 \%$ was 1.4 (95\% C I $0.8,2.5$; $\mathrm{p}=$ 0.2 ). When CD4 percentage was analysed on a continuum, the adjusted mortality rate ratio was 1.3 (95\% C I $0.98,1.7: \mathrm{p}=0.07$ ) for every absolute $10 \%$ decrease in CD4.

\section{Changes in HIV-2 plasma viral load and CD4\% over time}

Table 5 shows the plasma viral load and CD $4 \%$ among HIV-2 infected subjects during follow-up. The proportion of HIV-2 infected subjects who were alive and had not been censored due to loss to follow-up or HIV-1 seroconversion, from whom viral load was available in 1991, 1996, 2003, and 2006 were 98\%, 78\%, 77\% and $61 \%$ respectively; the corresponding proportions for CD4 measurements were $94 \%, 74 \%, 72 \%$ and $61 \%$. The median plasma viral load of those tested did not differ significantly between the time points $(p=0.5)$ whereas the median CD4\% showed a small increase over time ( $\mathrm{p}=$ 0.01). Plasma viral load measured in 1996, 2003 and 2006 was correlated with baseline (1996: $\mathrm{r}=0.68, \mathrm{p}<0.001, \mathrm{n}=$ 76; 2003: $\mathrm{r}=0.53, \mathrm{p}<0.001, \mathrm{n}=47 ; 2006: \mathrm{r}=0.38, \mathrm{p}=$ $0.04, \mathrm{n}=31$ ), although this correlation decreased over time.

Changes in plasma viral load over time were also analysed according to follow-up status (died, lost to follow-up or censored, and alive). The median change between 1991 and 2003 among those alive in 2006 was 0 (IQR -57, 657 copies per $\mathrm{ml} ; \mathrm{n}=27$ ), and this was similar to those who were lost to follow-up or censored (0, IQR -632, 1082 copies per $\mathrm{ml} ; \mathrm{n}=12)(\mathrm{p}=0.8)$. The median change between 1991 and 2003 for those who died after 2003 was 20,236 (IQR -780, 57,328 copies per $\mathrm{ml} ; \mathrm{n}=6)(\mathrm{p}=0.1$ ).

Thirty-one subjects had plasma viral load measurements, and 30 were tested for CD4\% in both 1991 and 2006. Their median (IQR) age at baseline was $46(41,57)$ years. The median (IQR) plasma viral load was 105 (50, $335)$ and $171(50,497)$ copies per $\mathrm{ml}$ respectively and median (IQR) CD4 percentage $29 \%(25,35)$ and $33 \%(27$, $42)$ respectively. Fifteen $(48 \%)$ had undetectable plasma viral load in 1991, of whom 13 (42\%) had maintained an undetectable viral load 15 years later in 2006.

\section{Discussion}

The disease course and pathogenicity of HIV-2 infections are recognised to differ from HIV-1, although detailed descriptions of long-term survival with HIV-2 over prolonged periods have not been fully documented. In this unique 18-year community-based study conducted in rural Guinea -Bissau, we have demonstrated the mortality of HIV-2 infected subjects to be approximately twice that of HIV-uninfected subjects. This confirms findings from 


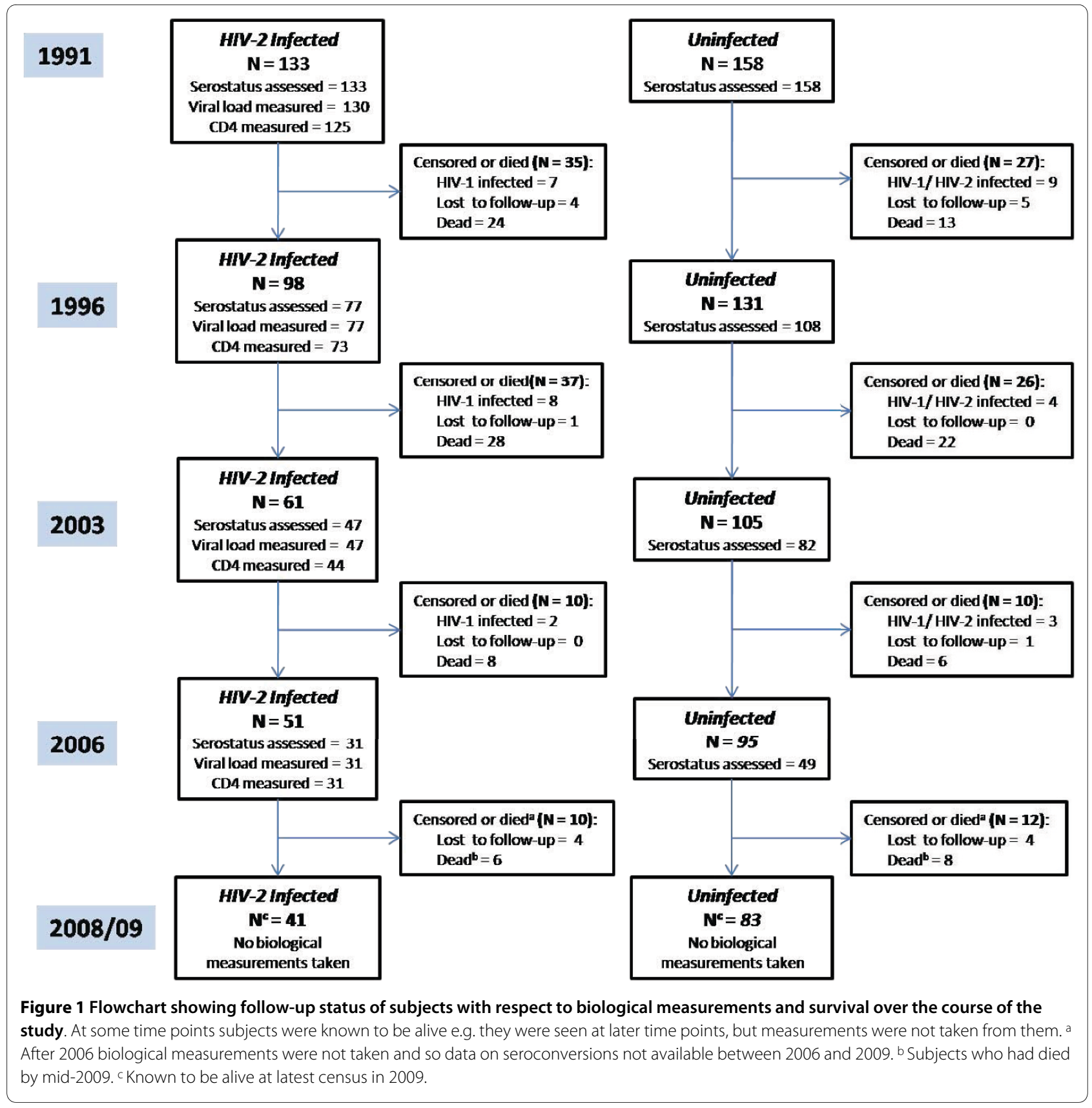

studies which had shorter durations of follow-up $[9,10,12,20,22]$ and extends the earlier observations of this cohort [20]. Mortality rate ratios of HIV-2-infected and HIV-uninfected decreased with age (at enrolment). In fact the rate ratios diminished with time either because background mortality of the elderly is high or because many of the HIV-2 infected old people were long term non-progressors with a normal lifespan. Mortality, after adjusting for age, was lower in women than men who also have higher plasma viral load. In contrast mortality in rural Uganda was increased 10 fold in HIV-1 infected subjects and was similar for men and women. In the
Ugandan study, those over the age of 55 years died more rapidly than younger patients or their age matched uninfected counterparts [6].

Ascertainment of vital status was good in this closeknit rural West African community, with a total loss to follow up of only $6.5 \%$. However, follow up sampling for laboratory tests was less satisfactory as, apart from those who died, many subjects were not in the village at the time of the surveys or were identified to have seroconverted to HIV-1, so were censored. Thus, the longitudinal aspects of the laboratory studies need to be interpreted with some caution as the outcomes of those not retested 
Table 2: Baseline characteristics (in 1991) of subjects according to HIV diagnosis and follow-up status in $2008 / 09$.

\begin{tabular}{|c|c|c|c|c|c|c|}
\hline & \multicolumn{3}{|c|}{ HIV-2 infected } & \multicolumn{3}{|c|}{ HIV-uninfected } \\
\hline & $\begin{array}{l}\text { Alive in mid } \\
2009(N=41)\end{array}$ & $\begin{array}{l}\text { Died by mid } \\
2009(N=66)\end{array}$ & $\begin{array}{l}\text { Lost or } \\
\text { censored by } \\
\text { mid 2009 } \\
(N=26)\end{array}$ & $\begin{array}{l}\text { Alive in mid } \\
2009(N=83)\end{array}$ & $\begin{array}{l}\text { Died by mid } \\
2009(N=49)\end{array}$ & $\begin{array}{l}\text { Lost or } \\
\text { censored by } \\
\text { mid 2009 } \\
(N=26)\end{array}$ \\
\hline \multicolumn{7}{|l|}{$\begin{array}{l}\text { Sex, number } \\
\text { (\%) }\end{array}$} \\
\hline Male & $12(29)$ & $27(64)$ & $3(7)$ & $18(42)$ & $20(47)$ & $5(12)$ \\
\hline Female & $29(32)$ & $39(43)$ & $23(25)$ & $65(57)$ & $29(25)$ & $21(18)$ \\
\hline $\begin{array}{l}\text { Age in years, } \\
\text { median (IQR) }\end{array}$ & $45(33,55)$ & $56(42,66)$ & $43(37,49)$ & $41(28,52)$ & $63(51,71)$ & $42(37,53)$ \\
\hline $\begin{array}{l}\text { CD4 } \\
\text { percentage, } \\
\text { median (IQR) }\end{array}$ & $32(25,40)$ & $25(18,32)$ & $32(26,35)$ & & & \\
\hline $\begin{array}{l}\text { Plasma viral } \\
\text { load copies } \\
\text { per } m \text { I, } \\
\text { median (IQR) }\end{array}$ & $79(50,775)$ & $\begin{array}{c}1630(127 \\
12,225)\end{array}$ & $90(50,530)$ & & & \\
\hline
\end{tabular}

are not known (though their baseline characteristics were broadly similar to those who were re-sampled). In addition we do not know precisely when the subjects in our cohort were infected with HIV-2, but even if infection was acquired recently and the death rate was high among those lost to follow-up, our study confirms that many HIV-2 infected subjects may have a long-lifespan.
Baseline plasma viral load among our HIV-2 cohort was generally very low as previously reported [20]. Plasma viral load was undetectable in $37 \%$ of the subjects who had a normal lifespan; this is in sharp contrast to almost all community-based HIV-1 studies in Africa. For example, in a study among pregnant women in Gambia only $3 \%$ of HIV-1 infected subjects had an undetectable viral load, and the median viral load was 30-40 fold higher

Table 3: Crude mortality rates by age and sex among HIV-2 - infected and HIV uninfected individuals.

\begin{tabular}{|c|c|c|c|c|c|}
\hline & \multicolumn{2}{|c|}{ HIV-2 infected } & \multicolumn{2}{|c|}{ HIV-uninfected } & \multirow[b]{2}{*}{$\begin{array}{c}\text { Rate ratio (95\% } \\
\mathrm{CI})\end{array}$} \\
\hline & $\begin{array}{c}\text { Number died/ } \\
\text { total per } \\
\text { category }(\%)\end{array}$ & $\begin{array}{l}\text { Mortality rate } \\
\text { per } 100 \text { person- } \\
\text { years }(95 \% \mathrm{CI})\end{array}$ & $\begin{array}{c}\text { Number died/ } \\
\text { total per } \\
\text { category }(\%)\end{array}$ & $\begin{array}{l}\text { Mortality rate } \\
\text { per } 100 \text { person- } \\
\text { years }(95 \% \mathrm{Cl})\end{array}$ & \\
\hline \multicolumn{6}{|l|}{ Age group ${ }^{a, b}$} \\
\hline$<40$ & $15 / 37(41)$ & $3.4(2.0,5.6)$ & $7 / 56(13)$ & $0.8(0.4,1.7)$ & $4.2(1.7,10.2)$ \\
\hline $40-59$ & 23/59 (39) & $3.4(2.3,5.1)$ & $15 / 63(24)$ & $1.6(1.0,2.7)$ & $2.1(1.1,4.1)$ \\
\hline$\geq 60$ & $28 / 36(78)$ & $8.5(5.9,12.3)$ & 27/39 (69) & $5.8(4.0,8.5)$ & $1.5(0.9,2.5)$ \\
\hline \multicolumn{6}{|l|}{ Sex } \\
\hline Male & $27 / 42(64)$ & $6.1(4.2,8.8)$ & $20 / 43(46)$ & $3.7(2.4,5.8)$ & $1.6(0.9,2.9)$ \\
\hline Female & $39 / 91$ (43) & $3.9(2.8,5.3)$ & $29 / 115(25)$ & $1.7(1.2,2.4)$ & $2.3(1.4,3.7)$ \\
\hline \multicolumn{6}{|l|}{ Calendar time } \\
\hline 1991-1998 & $37 / 133(28)$ & $4.3(3.1,6.0)$ & 24/158 (15) & $1.9(1.3,2.8)$ & $2.3(1.4,3.8)$ \\
\hline 1999-2009 & $29 / 84(35)$ & $4.8(3.4,7.0)$ & $25 / 120(21)$ & $2.5(1.7,3.7)$ & $1.9(1.1,3.3)$ \\
\hline Overall & $66 / 133(50)$ & $4.5(3.6,5.8)$ & 49/158 (31) & $2.2(1.6,2.9)$ & $2.1(1.5,3.0)$ \\
\hline
\end{tabular}

${ }^{a}$ Age at enrolment

bMissing data for one individual 

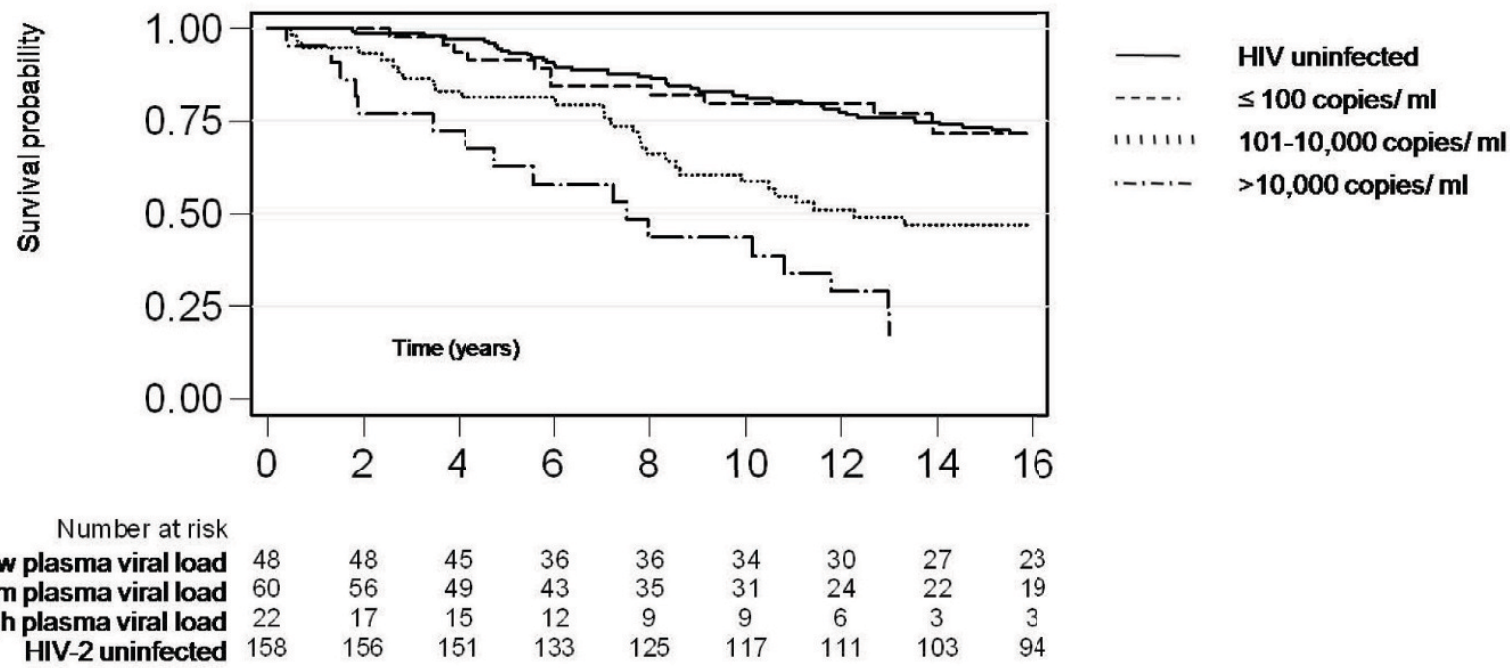

Figure 2 Kaplan-Meier survival of HIV-2 infected (stratified by baseline plasma viral load) and HIV-uninfected subjects

[24]. In the much smaller proportion (17\%) of HIV-2 infected subjects in Caio with a high viral load $(>10,000$ copies per $\mathrm{ml}$ ) these had greatly decreased survival, as has been found in HIV-1 infection in Bissau and The Gambia $[11,18]$.

Both HIV-2 plasma viral load and CD4 percentage predicted survival. The association with HIV-2 plasma viral load was very strong; and in multivariable analysis mortality among those with plasma viral load exceeding
10,000 HIV-2 RNA copies per ml was 5 fold higher than in those with undetectable plasma viral load, whose mortality rate was not appreciably different from that in HIV2 -uninfected subjects. The association between CD4 percentage and survival was weaker and lost significance after adjusting for age, sex and plasma viral load. Our results confirm those of previous studies showing lower viral replication in HIV-2, which suggested that HIV-2 plasma viral load may predict prognosis [13,17-20]. We

Table 4: Association between CD4 percentage, plasma viral load measured in 1991 and mortality over a 18 year follow-up among HIV-2 infected subjects.

\begin{tabular}{|c|c|c|c|c|c|c|}
\hline & \multirow[b]{2}{*}{ Number } & \multirow[b]{2}{*}{$\begin{array}{c}\text { Mortalityrate } \\
\text { per } 100 \\
\text { person-years } \\
(95 \% \mathrm{Cl})\end{array}$} & \multicolumn{2}{|c|}{ Univariable } & \multicolumn{2}{|l|}{ Multivariable $^{a}$} \\
\hline & & & $\begin{array}{c}\text { Rate ratio } \\
(95 \% \mathrm{Cl})\end{array}$ & & $\begin{array}{c}\text { Rate ratio } \\
(95 \% \mathrm{Cl})\end{array}$ & P value \\
\hline \multicolumn{7}{|c|}{ Plasma viral load $b$, copies per $m l$} \\
\hline$\leq 100$ & $15 / 48(31)$ & $2.4(1.4,4.0)$ & 1.0 & $<0.001$ & 1 & $<0.001$ \\
\hline $\begin{array}{l}101- \\
10,000\end{array}$ & $31 / 60(52)$ & $4.9(3.5,7.0)$ & $2.0(1.1,3.8)$ & & $2.0(1.0,4.2)$ & \\
\hline$>10,000$ & $18 / 22(82)$ & $10.4(6.6,16.5)$ & $4.3(2.2,8.6)$ & & $5.6(2.5,12.5)$ & \\
\hline \multicolumn{7}{|c|}{ CD4 percentage ${ }^{c}$} \\
\hline$\geq 28 \%$ & $26 / 70(37)$ & $3.1(2.1,4.6)$ & 1.0 & 0.007 & 1 & 0.2 \\
\hline$<28 \%$ & $34 / 55(62)$ & $6.3(4.5,8.8)$ & $2.0(1.2,3.3)$ & & $1.4(0.8,2.5)$ & \\
\hline
\end{tabular}

a Adjusted for age category, sex, CD4 percentage and plasma viral load

b Missing data for 3 individuals

c Missing data for 8 individuals 
Table 5: Changes in HIV-2 plasma viral load and CD4 percentage over time.

\begin{tabular}{|c|c|c|c|c|}
\hline & $\begin{array}{c}1991 \\
(N=133)\end{array}$ & $\begin{array}{c}1996 \\
(N=97)\end{array}$ & $\begin{array}{c}2003 \\
(N=47)\end{array}$ & $\begin{array}{c}2006 \\
(N=31)\end{array}$ \\
\hline \multicolumn{5}{|c|}{ Plasma viral load, copies ml } \\
\hline Median (IQR)a & $348(50,4,300)$ & $150(50,1,554)$ & $203(50,2,837)$ & $171(50,497)$ \\
\hline $\begin{array}{l}\text { Median change } \\
(\mathrm{IQR})^{\mathrm{b}}\end{array}$ & $\mathrm{N} / \mathrm{A}$ & $0(-140,825)$ & $0(0,1,534)$ & $0(-2,373)$ \\
\hline \multicolumn{5}{|c|}{$\begin{array}{l}\text { Category, number } \\
\text { (\%) }\end{array}$} \\
\hline$<100$ & $48(36)$ & $33(42)$ & $20(43)$ & $13(42)$ \\
\hline $100-9,999$ & $60(45)$ & $32(41)$ & $19(40)$ & $16(52)$ \\
\hline$\geq 10,000$ & $22(17)$ & $12(15)$ & $8(17)$ & $2(6)$ \\
\hline Not tested & $3(2)$ & $1(1)$ & $0(0)$ & $0(0)$ \\
\hline \multicolumn{5}{|c|}{ CD4+ (\% of lymphocytes) } \\
\hline Median (IQR)c & $29(22,35)$ & $32(26,38)$ & $32(26,37)$ & $33(27,43)$ \\
\hline $\begin{array}{l}\text { Median change } \\
(\mathrm{IQR})^{\mathrm{d}}\end{array}$ & $\mathrm{N} / \mathrm{A}$ & $3(-4,8)$ & $3(-1,8)$ & $5(-2,9)$ \\
\hline \multicolumn{5}{|l|}{ Category } \\
\hline$\geq 28 \%$ & $70(53)$ & $48(61)$ & $28(60)$ & $22(71)$ \\
\hline$<28 \%$ & $55(41)$ & $25(32)$ & $16(34)$ & $9(29)$ \\
\hline Not tested & $8(6)$ & $5(6)$ & $3(6)$ & $0(0)$ \\
\hline
\end{tabular}

are unable to say with certainty how plasma viral load changed over time in those who died since our sampling was not done with sufficient frequency. However, in the small number tested there was a large but statistically non-significant rise in plasma viral load (median increase 20,000 copies $/ \mathrm{ml}$ ) in the 12 year period before their death.

Importantly, and for the first time, we have shown that amongst the survivors who were followed-up successfully and did not seroconvert to HIV-1, plasma viral load did not change appreciably over the 18 years of follow-up. Thus, there is a substantial proportion of individuals in HIV-2 infection in whom viral load remains set and stable at a very low level over decades, compared to the much higher set points typically described for HIV-1 [25]. Understanding the biological significance of this observation seems key to unravelling differences in the enhanced survival of the majority of HIV-2 subjects compared to HIV-1. Both host genetic and viral factors are likely to be important. The same HIV-2 subjects with a low or undetectable viral load and a normal CD4 percentage have been shown to have strong T-cell responses to the HIV-2 gag protein, particularly directed towards the highly conserved region represented by peptide 46 in the Major
Homology Region [23,26]. The findings raise the intriguing possibility of developing a therapeutic vaccine targeted at the gag epitopes identified in this study for the treatment of those with progressive disease. As viral load is already well controlled in the majority of subjects, the chances of success may be higher than in HIV-1 infection. However, there remains a small proportion of subjects where host control of virus infection has failed, in those with a high viral load and a mortality rate similar to those with HIV-1 infection. An analogous situation has been described in wild chimpanzees infected with an SIV chimpanzee strain (SIVcpz), thought to have evolved after the transmission of a SIV from red-capped sooty mangabey monkeys [27], where a higher viral load also correlates with mortality. Current research based on the cohort suggests that high viral load is associated with HLA B*1503 subtype which is common in the Manjago ethnic group and confined to populations in sub-Saharan Africa [28]. A previous study of viral genotype in Caio village in which sequencing was limited to a small proportion of the genome, suggested that viral genotype determined disease progression and that virulence factors are multiple and scattered through out the genome [29]. A recent analysis of HIV-2 p26 capsid variation in 
plasma viral sequences rescued from this cohort has shown that a proline in positions 119,159 and178 in the capsid protein predicts a low viral load. Conversely if other amino acids are occupying these positions the viral load is high [30]. The study raises interesting questions as to how the low-replicating proline mutants are maintained in the population, as transmission is strongly related to viral load.

\section{Conclusion}

This unique field study of HIV-2 infection in a rural community demonstrates the power of coupling good epidemiological data with detailed laboratory investigations. Divergent patterns of viral pathogenicity have resulted in two distinct clinical outcomes which provide a great opportunity to examine the key elements of host protection and viral virulence. Further studies need to be informed by complete sequencing of host and viral genomes and a deeper understanding of their phenotypic interactions. Such basic knowledge is sorely needed to understand correlates of immunity and their effect on the evolution of the virus, which will inform the design of HIV vaccines which to date have met with little success.

Competing interests

The authors declare that they have no competing interests.

\section{Authors' contributions}

MS was responsible for field work and wrote the first draft of the paper. NL did the statistical analysis. SK, NB, KA, AA, AL, RSN, ZdS and AJ, and SRJ were responsible for the laboratory analyses. TV, AL, CVT and PA organised and COordinated the follow-up of subjects. SJ wrote subsequent drafts of the paper. DR and HW designed the original study with help from PA. HW gave overall direction to the project and wrote the last draft with help from SRJ All authors commented on drafts of the paper.

\section{Acknowledgements}

This paper is dedicated to the memory of Andrew Wilkins who planned this study and executed so many fine epidemiological studies in West Africa. We would like to thank the participants in the study, as well as the team of field workers and laboratory staff. Special thanks to Akum Aveika Awasana, Marianne van der Sande, Sam McConkey, Carlos da Costa, Pauline Kaye, Sangeeta Dave, Akram Zaman and Francisco Dias. We acknowledge the continued support of the Ministry of Health from Guinea-Bissau.

The study was funded by the Medical Research Council, UK.

\begin{abstract}
Author Details
${ }^{1}$ MRC Laboratories Fajara, P.O. Box 273, Banjul, The Gambia, 2Department of Epidemiology and Population Health, London School of Hygiene \& Tropical Medicine, Keppel Street, London WC1E 7HT, UK, 32Division of Retrovirology, National Institute of Biological Standards and Control/HPA, South Mimms, UK, ${ }^{4}$ Department of Clinical Medicine, Institute of Tropical Medicine, Nagasaki University, Nagasaki, Japan and 5Bandim Health Project, Indepth network, Bissau, Guinea-Bissau
\end{abstract}

Received: 9 December 2009 Accepted: 19 May 2010 Published: 19 May 2010

\section{References}

1. Lemey P, Pybus OG, Wang B, Saksena NK, Salemi M, Vandamme AM: Tracing the origin and history of the HIV-2 epidemic. Proc Natl Acad Sci USA 2003, 100:6588-6592.
2. Rowland-Jones SL, Whittle HC: Out of Africa: what can we learn from HIV-2 about protective immunity to HIV-1? Nat Immunol 2007, 8:329-331

3. Poulsen AG, Aaby P, Gottschau A, Kvinesdal BB, Dias F, Molbak K, Lauritzen E: HIV-2 infection in Bissau, West Africa, 1987-1989: incidence, prevalences, and routes of transmission. J Acquir Immune Defic Syndr 1993, 6:941-948.

4. da Silva ZJ, Oliveira I, Andersen A, Dias F, Rodrigues A, Holmgren B, Andersson S, Aaby P: Changes in prevalence and incidence of HIV-1, HIV-2 and dual infections in urban areas of Bissau, Guinea-Bissau: is HIV-2 disappearing? AIDS 2008, 22:1195-1202.

5. Jaffar S, Grant AD, Whitworth J, Smith PG, Whittle H: The natural history of HIV-1 and HIV-2 infections in adults in Africa: a literature review. Bull World Health Organ 2004, 82:462-469.

6. Morgan D, Mahe C, Mayanja B, Okongo JM, Lubega R, Whitworth JA: HIV1 infection in rural Africa: is there a difference in median time to AIDS and survival compared with that in industrialized countries? AIDS 2002, 16:597-603.

7. Mellors JW, Munoz A, Giorgi JV, Margolick JB, Tassoni CJ, Gupta P, Kingsley LA, Todd JA, Saah AJ, Detels R, Phair JP, Rinaldo CR Jr: Plasma viral load and CD4+ lymphocytes as prognostic markers of HIV-1 infection. Ann Intern Med 1997, 126:946-954.

8. Mellors JW, Rinaldo CR Jr, Gupta P, White RM, Todd JA, Kingsley LA: Prognosis in HIV-1 infection predicted by the quantity of virus in plasma. Science 1996, 272:1167-1170.

9. Schim van der Loeff MF, Jaffar S, Aveika AA, Sabally S, Corrah T, Harding E, Alabi A, Bayang A, Ariyoshi K, Whittle HC: Mortality of HIV-1, HIV-2 and HIV-1/HIV-2 dually infected patients in a clinic-based cohort in The Gambia. AIDS 2002, 16:1775-1783.

10. Whittle H, Morris J, Todd J, Corrah T, Sabally S, Bangali J, Ngom PT, Rolfe M, Wilkins A: HIV-2-infected patients survive longer than HIV-1-infected patients. AIDS 1994, 8:1617-1620.

11. Holmgren B, da Silva Z, Vastrup $P$, Larsen $O$, Andersson $S$, Ravn H, Aaby P: Mortality associated with HIV-1, HIV-2, and HTLV-I single and dual infections in a middle-aged and older population in Guinea-Bissau. Retrovirology 2007, 4:85.

12. Poulsen AG, Aaby P, Larsen $O$, Jensen $H$, Naucler A, Lisse IM, Christiansen CB, Dias F, Melbye M: 9-year HIV-2-associated mortality in an urban community in Bissau, west Africa. Lancet 1997, 349:911-914.

13. Berry N, Ariyoshi K, Jaffar S, Sabally S, Corrah T, Tedder R, Whittle H: Low peripheral blood viral HIV-2 RNA in individuals with high CD4 percentage differentiates HIV-2 from HIV-1 infection. J Hum Virol 1998, 1:457-468.

14. Jaffar S, Wilkins A, Ngom PT, Sabally S, Corrah T, Bangali JE, Rolfe M, Whittle HC: Rate of decline of percentage CD4+ cells is faster in HIV-1 than in HIV-2 infection. J Acquir Immune Defic Syndr Hum Retrovirol 1997, 16:327-332.

15. Lisse IM, Poulsen AG, Aaby P, Knudsen K, Dias F: Serial CD4 and CD8 Tlymphocyte counts and associated mortality in an HIV-2-infected population in Guinea-Bissau. J Acquir Immune Defic Syndr Hum Retrovirol 1996, 13:355-362.

16. Marlink R, Kanki P, Thior I, Travers K, Eisen G, Siby T, Traore I, Hsieh CC, Dia MC, Gueye EH, et al:: Reduced rate of disease development after HIV-2 infection as compared to HIV-1. Science 1994, 265:1587-1590.

17. Alabi AS, Jaffar S, Ariyoshi K, Blanchard T, Schim van der Loeff M, Awasana AA, Corrah T, Sabally S, Sarge-Njie R, Cham-Jallow F, Jaye A, Berry N, Whittle $\mathrm{H}$ : Plasma viral load, CD4 cell percentage, HLA and survival of HIV-1, HIV-2, and dually infected Gambian patients. AIDS 2003, 17:1513-1520.

18. Hansmann A, Schim van der Loeff MF, Kaye S, Awasana AA, Sarge-Njie R, O'Donovan D, Ariyoshi K, Alabi A, Milligan P, Whittle HC: Baseline plasma viral load and CD4 cell percentage predict survival in HIV-1- and HIV-2infected women in a community-based cohort in The Gambia. J Acquir Immune Defic Syndr 2005, 38:335-341.

19. Jaffar S, Loeff MS Van der, Eugen-Olsen J, Vincent T, Sarje-Njie R, Ngom P, Meyer AM, Berry N, Aaby P, Whittle H: Immunological predictors of survival in HIV type 2-infected rural villagers in Guinea-Bissau. AIDS Res Hum Retroviruses 2005, 21:560-564.

20. Berry N, Jaffar S, Schim van der Loeff M, Ariyoshi K, Harding E, N'Gom PT, Dias F, Wilkins A, Ricard D, Aaby P, Tedder R, Whittle H: Low level viremia 
and high CD4\% predict normal survival in a cohort of HIV type-2infected villagers. AIDS Res Hum Retroviruses 2002, 18:1167-1173.

21. Wilkins A, Ricard D, Todd J, Whittle H, Dias F, Paulo Da Silva A: The epidemiology of HIV infection in a rural area of Guinea-Bissau. AIDS 1993, 7:1119-1122.

22. Ricard D, Wilkins A, N'Gum PT, Hayes R, Morgan G, Da Silva AP, Whittle H: The effects of HIV-2 infection in a rural area of Guinea-Bissau. AIDS 1994, 8:977-982.

23. Leligdowicz A, Yindom LM, Onyango C, Sarge-Njie R, Alabi A, Cotten M, Vincent T, da Costa C, Aaby P, Jaye A, et al:: Robust Gag-specific T cell responses characterize viremia control in HIV-2 infection. J Clin Invest 2007, 117:3067-3074.

24. O'Donovan D, Ariyoshi K, Milligan P, Ota M, Yamuah L, Sarge-Njie R, Whittle $\mathrm{H}$ : Maternal plasma viral RNA levels determine marked differences in mother-to-child transmission rates of HIV-1 and HIV-2 in The Gambia. MRC/Gambia Government/University College London Medical School working group on mother-child transmission of HIV. AIDS 2000, 14:441-448.

25. O'Brien TR, Rosenberg PS, Yellin F, Goedert JJ: Longitudinal HIV-1 RNA levels in a cohort of homosexual men. J Acquir Immune Defic Syndr Hum Retrovirol 1998, 18:155-161.

26. Ariyoshi K, Cham F, Berry N, Jaffar S, Sabally S, Corrah T, Whittle H: HIV-2specific cytotoxic T-lymphocyte activity is inversely related to proviral load. AIDS 1995, 9:555-559.

27. Keele BF, Jones JH, Terio KA, Estes JD, Rudicell RS, Wilson ML, Li Y, Learn GH, Beasley TM, Schumacher-Stankey J, Wroblewski E, Mosser A, Raphael J, Kamenya S, Lonsdorf EV, Travis DA, Mlengeya T, Kinsel MJ, Else JG, Silvestri G, Goodall J, Sharp PM, Shaw GM, Pusey AE, Hahn BH: Increased mortality and AIDS-like immunopathology in wild chimpanzees infected with SIVcpz. Nature 2009, 460:515-519.

28. Yindom LM, Leligdowicz A, Martin MA, Gao X, Qi Y, Zaman A, Schim van der Loeff M, van Tienen C, Jaye A, Aveika AA, et al:: HLA class and HLA-KIR compound genotypes predict HIV-2 infection and disease progression in a manjako community in Caio, Guinea Bissau. J Virol 2009.

29. Grassly NC, Xiang Z, Ariyoshi K, Aaby P, Jensen H, Schim van der Loeff M, Dias F, Whittle H, Breuer J: Mortality among human immunodeficiency virus type 2-positive villagers in rural Guinea-Bissau is correlated with viral genotype. J Virol 1998, 72:7895-7899.

30. Onyango C, Leligdowicz A, Yokoyma M, Sato H, Song H, Nakayama E, Shioda T, De Silva T, Townend J, Jaye A, et al:: HIV-2 capsids distinguish high and low virus load patients in a West African Community Cohort. Vaccine 2010 in press.

\section{doi: 10.1186/1742-4690-7-46}

Cite this article as: van der Loeff et al., Undetectable plasma viral load predicts normal survival in HIV-2-infected people in a West African village Retrovirology 2010, 7:46

\section{Submit your next manuscript to BioMed Central} and take full advantage of:

- Convenient online submission

- Thorough peer review

- No space constraints or color figure charges

- Immediate publication on acceptance

- Inclusion in PubMed, CAS, Scopus and Google Scholar

- Research which is freely available for redistribution

Submit your manuscript at www.biomedcentral.com/submit
C Biomed Central 